\title{
RETHINKING THE SHADOW ECONOMY IN TERMS OF HAPPINESS. EVIDENCE FOR THE EUROPEAN UNION MEMBER STATES
}

\author{
Monica Violeta ACHIMa, Sorin Nicolae BORLEA ${ }^{\mathrm{b}}$, \\ Lucian Vasile GĂBANc, Ionut Constantin CUCEU ${ }^{\mathrm{a}}$ \\ ${ }^{a}$ Department of Finance, Faculty of Economics and Business Administration, \\ Babeș-Bolyai University, Cluj-Napoca, Romania \\ ${ }^{b}$ Department of Accounting and Finance, Faculty of Economics, Informatics and Engineering \\ West Vasile Goldis University, Arad, Romania \\ 'Faculty of Science, "1 Decembrie 1918" University, Alba Iulia, Romania
}

Received 26 January 2015; accepted 06 February 2016

\begin{abstract}
This paper's goal is to highlight how happiness affects the level of shadow economy, by using many control variables within different types of potentially determining factors of shadow economy. Another main contribution consists in the systematic comparison between old and new European Union member states in terms of determinants of shadow economy, including happiness. Our findings consist in the fact that happier people are more likely to act honestly, thus causing a decrease in the size of shadow economy and this result is valid both for old and new European Union countries. In addition, we found that the quality of public governance and the richness of a country are associated with a lower propensity towards shadow economy for all the member states. However, the relationship between public governance and shadow economy are never significant when the happiness and richness variables vary simultaneously. Our research reveals that the shadow economy in European Union countries is explained in percent of about $62 \%$ by richness and happiness of the people. Contrary to our expectations, the fiscal pressure seems not to be a determinant for shadow economy in the European Union space.
\end{abstract}

Keywords: happiness, shadow economy, public governance, fiscal burden, richness

JEL Classification: A12, A13, H 26.

\section{Introduction}

Current research of the economic phenomena goes beyond the economic explanations, emphasizing the role of social and psychological dimension. Stiglitz et al. (2010) highlights the importance of measuring a nation's emotional prosperity rather than its economic prosperity, focusing on well-being than wealth. Oswald (2010), a pioneer of happiness economics

Corresponding author Monica Violeta Achim

E-mail: monica.achim@econ.ubbcluj.ro 
and a member of the Stiglitz Comission, reveals that the research area in the economics field could consist in emotional prosperity. Therefore, many behavioral acts in the economics field are better explained. Also, he remarks that the borders between economics and other social science disciplines could become increasingly blurred.

Two decades ago, Robinson and Shaver (1991) identified more than 347000 specialized psychological studies in area of "happiness", "subjective well-being" or "life satisfaction". Roubal and Havliček (2013) have recently made a broad research on the role of happiness in the economic environment.

Over time, in spite of the fact that numerous studies have analyzed the impact of psychology factors on the economic behavior of people, few studies have discussed whether well-being and happiness comes to affect the level of shadow economy. They presumed that if people were happier, they would be more inclined to have respect for the law. This way, the level of the shadow economy would reduce. Few studies have investigated this field (Schneider, Klinglmair 2004; Bergheim 2007; Thießen 2010) and the results are not fully convincing. The main aim of this study is to cover this gap in the literature by investigating the relation between happiness and the size of shadow economy, controlling in a multivariate analysis for a diversity of factors.

A second aim is to answer at this research question: Is there a difference between the old and the new EU member states with regard the shadow economy and how this variation can be explained by the factors which act in each of these two groups?

Moreover, in the literature discussed so far we have not identified a similar study, analyzing the variation of the shadow economy starting from the explanatory factors which belong to old European Union members (EU 15) and new European Union entrants (EU 13). The theoretical basis for this comparison comes from different fields of research, which point out the specific characteristics for each of the two groups. Firstly, the differences between these two categories of countries are significant in terms of economic development, as long as the majority of the old EU members are developed countries and the new EU members are emerging ones. The specific features of emerging countries are also commonly recognized to alter the major forces which play an active role in economy. Therefore, Earnhart and Lizal (2007) evidence in their research among several emerging European economies that emerging countries have specific economic, social and political conditions. They found a series of factors such as privatization, legislation context, public influence, export orientation that create specific conditions in which the same factors have different effects as in developed countries. We can also point out the effects of board heterogeneity which characterize the emerging economies and the extent to which these influence the business performances (Mahadeo et al. 2012). Secondly, the extent of Europeanization's process, which is differentially applied by the new European Union members compared to the old entrants, could be a real reason for these differences (Goetz 2001; Grabbe 2001). The level of compliance to EU rules by the EU members is directly related to the process of Europeanization. The difficulties of implementing EU law by the new EU members compared with the old EU members are also largely analyzed by Falkner and Treib (2008) in order to establish whether or not the new EU members represent a separate world of compliance compared to the EU 15 old members. Based on the specific characteristics of 
each of the two groups (the old EU 15 and the new EU 13 member states), Tosun (2014) also considers these two groups in order to evaluate the absorption performance with regard to the European Regional Development Fund's (ERDF).

Due to the specific features of each of the two groups, we join these authors, this time for analyzing the shadow economy. Also, we may expect that in the NEW EU members the variation of the shadow economy can be differentially explained by the factors which characterize these countries compared with the OLD EU ones.

Our paper is structured as follows. In Section 1, the theoretical considerations are set up, according to which the working hypotheses and the research questions are stated. In Section 2, we design methodology and data sources. In order to substantiate the econometric model of shadow economy we consider several control variables largely used by the literature in the field. Section 3 highlights the results and discussions of the main empirical findings. The paper ends with the conclusions including a summary and a brief discussions of policy implications, limitations and the avenues for future research.

\section{Theoretical considerations and assessing the main working hypotheses}

The undertaking to identify a causal relationship between human happiness or well-being of citizens and the size of shadow economy begins with the study of Frey and Stutzer (2012) which acts as a synthesis and highlights that the extent of happiness may influence many important economic decisions such as working behavior, consumption activities, investment behavior and political behavior. Kahneman et al. (2006) and Goossens et al. (2007) also focused on the attempts to augment GDP by "happiness".

Many authors appreciate that psychological causes with reference to human nature are considered the most important determinants of shadow economy (Voicu 2012).

If the well-being and state of contentment of people are more pronounced, they are more inclined to pay the taxes they owe the state. This way, tax morale and tax compliance are directly related to tax evasion and shadow activities. The tax morale concept was introduced by Schmölders in 1960 and it is related to feelings of civic and fiscal awareness among the citizens or taxpayers and the intrinsic motivation to pay taxes. Tax compliance is the degree to which taxpayers comply or fail to comply with the tax rules of their country, by declaring income, return and paying the tax due on time (OECD 2012). The economic literature has recently emphasized the importance of moral considerations or social norms to explain compliance behavior with respect to shadow activities. Furthermore, Halla (2010) analyzed the correlation between the intrinsic motivation to comply (tax morale) and compliance behavior (tax compliance), the relationship between attitude and behavior. Nevertheless his research does not bring evidence for such a correlation and thus the need of a good understanding of this relationship in future research remains addressed.

In the context of our study the concerns on studying the correlations between happiness and tax morale need to be mentioned. This way, the study of Akay et al. (2012) shows there are a few such concerns in literature. Moreover, the study of Antoci et al. (2014) found even fewer papers which explicitly attempt to formalize and incorporate these two variables into a theoretical model. Lubian and Zarri (2011), in their survey conducted on Italian house- 
holds in 2004, found empirical evidence that tax morale is a new determinant of happiness. According to their findings, cheating, as a synonym of tax evasion, is associated with lower levels of well-being than fiscal honesty and shows that honesty and cheating result in different significant hedonic consequences. These results are in line with the empirical and laboratory findings from neurological and economic studies of Harbaugh et al. (2007) and Coricelli et al. (2014). The findings of Coricelli et al. (2014) regarding the people who cheat are the following: "People do not only feel anxiety because of the monetary prospects of a risky decision, but also due to the moral implications associated with the risk of a public exposure". Tax morale and tax evasion dynamics are expressed differently in a behaviorally heterogeneous society and result from repeated interactions of three types of taxpayers (cheaters, honest citizens and punishers) (Antoci et al. 2014).

By identifying such a gap in literature, Akay et al. (2012) try to investigate the extent to which labor taxation (income and payroll taxes) affects individuals' well-being, by using the German Socio-Economic Panel from 1985 to 2010. They find that people are happier (in terms of subjective well-being) when they pay the taxes.

On the other hand, there are many studies that have tried to identify the way in which happiness, specifically the degree of happiness and contentment, represents a determining factor for tax morale or the citizens' willingness to pay their taxes. Torgler (2004) analyzes tax morale in several Asian countries and for the first time he empirical test the influence of happiness in some Asian countries such as India and the Philippines where many citizens have a low living standard. Compared to the other two variables considered namely financial satisfaction and satisfaction, the happiness variable is found to have the highest marginal effects on the tax morale. A similar study is conducted later by Tekeli (2011) in Japan and Turkey, having the purpose to find out if happier people are more likely to report honestly. This time, the results are inconsistent because in all cases the happiness variable does not significantly affect tax morale.

Even though the concerns regarding the analyze of the relationship between happiness and tax morale are very few (as seen above Torgler 2004; Tekeli 2011), the relationship between tax morale and shadow economy is much more addressed in the research field: Weck (1983), Torgler (2005) for Latin America; Alm, Torgler (2004) for the U.S. and Europe; Alm et al. (2005) for several transition countries; Torgler, Schneider $(2007,2009)$ on 57 countries around the world; Torgler et al. (2010) for different countries around the world; Barone, Mocetti (2009) for Italy; Halla (2010) for European countries, OECD countries but also for US and Australia. The majority of these studies found a significant negative effect of the tax morale on the size of shadow economy.

Based on the findings above, the following causality relations are stated: human happiness and tax morale, tax morale and tax compliance, tax morale/tax compliance and shadow economy. To sum up, we intend to find out if happier people are more likely to report honestly and therefore to reduce the size of shadow activities.

A few studies focus on investigating the causal relations between happiness or wellbeing and the size of the shadow economy. Schneider and Klinglmair (2004) find that in countries where people feel happy, shadow economy ranges between $8.6 \%$ and $18.7 \%$ of the reported GDP while in countries where people feel unhappy, shadow economy amounts 
to over $25 \%$ of the reported GDP. Bergheim (2007) identifies the indicator "small shadow economy" as a measure for a happy society, in a list of top ten indicators in which "small shadow economy" ranks the seventh. Thießen (2010), by using a OECD Panel Analysis, find that in a list of 67 factors with an impact upon the level of shadow economy, the corruption lies on the first place, then comes happiness and life satisfaction. He find that in small island countries such as Iceland and New Zealand the high level of happiness is positively correlated with a very small shadow economy (in the two decades before the crisis of 2009). However, he remarks these findings could be called into question as long as the island countries are not able to promote a very homogenous society and have a relatively high degree of ethnical diversity.

Therefore the following main hypothesis is stated:

Hypothesis 1. Increasing human happiness is associated with a lower propensity towards shadow economy.

As a secondary proposed objective, we formulate our main research question:

Research question 1. How the results of testing hypothesis 1differ for the two groups of EU countries (EU OLD and EU NEW)?

\section{Methodology and data}

\subsection{Measuring the dependent variable: Shadow economy}

The term "shadow economy" is also found in literature as synonym for "non-observed", "underground", "informal", "parallel" or "cash" economy.

According to $\operatorname{OECD}(2002,2008)$ and Eurostat (2014) the "non-observed" economy refers to all productive activities that may not be captured in the basic data source used for compiling national accounts (Table 1). It refers to the following activities:

1. Underground activities, defines as those activities that are productive and legal but are deliberately concealed from public authorities to avoid:

a) paying income, value added or other taxes;

b) paying for the social security contributions;

c) having to meet certain legal labor market standards, such as minimum wages, maximum hours, safety or health standards, etc.;

d) complying with certain administrative procedures, such as completing statistical questionnaires or other administrative forms".

2. Illegal activities, defines as those productive activities specifically cover by SNA (System of National Accounts) production boundary that:

a) generate goods and services forbidden by law (e.g. production and distribution of illegal drugs);

b) are unlawful when carried out by unauthorized producers (e.g. unlicensed practice of medicine). 
3. Production of household for own final use, defines as those productive activities that results in good or services consumes and capitalized by the household that produced them, such as:
a) production of crops and livestock;
b) production of other goods for their own and use;
c) construction of own houses and other own-account fixed capital formation;
d) imputed rents of owner occupiers and services of paid domestic servants.

4. Non-observed informal activities, being part of the informal sector also covering observed activities undertaken informally [...]"

Table 1. Delimiting the "observed" from "non-observed" economy

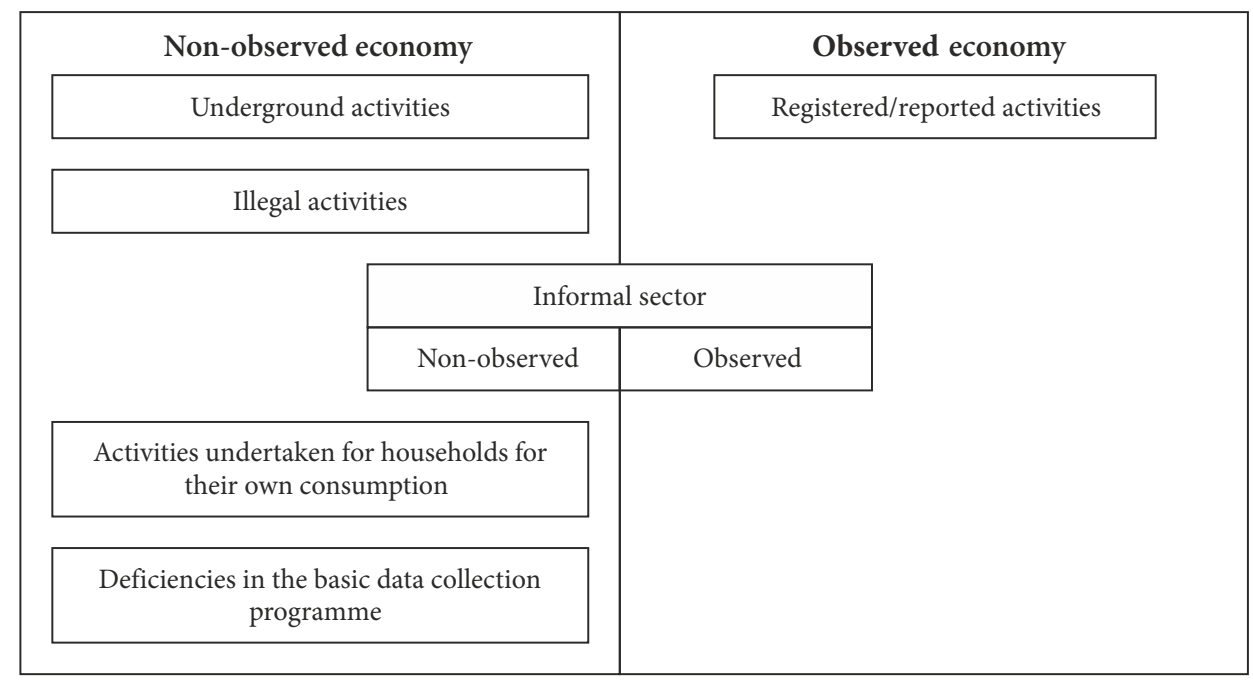

Source: Essential SNA: Building the basics (Eurostat 2014).

Although it is difficult to measure something that practically is unknown, many authors have strived to address such attempts. In various studies, Schneider and his colleagues set out to periodically measure the shadow economy in different states of the world and their initiatives are outstanding (Alm et al. 2004; Schneider, Klingmair 2004; Schneider et al. 2010, 2015; Schneider 2005, 2011, 2013).

In order to measure the shadow economy, in various studies conducted by Schneider and his contributors (Torgler, Schneider 2007; Schneider 2011, 2013) the following more narrow definition of the shadow economy is used:

"the shadow economy includes all market-based legal production of goods and services that are deliberately concealed from public authorities for the following:

a) to avoid paying income, value added or other taxes;

b) to avoid paying for the social security contributions;

c) to avoid having to meet certain legal labor market standards, such as minimum wages, maximum working hours, safety standards, etc., and 
d) to avoid complying with certain administrative procedures, such as completing statistical questionnaires or other administrative forms."

Having in mind the broad definition of "non-observed" economy given by OECD (2002, 2008) and Eurostat (2014), in order to get a better measure of shadow economy, Schneider retains only the first category of activities namely underground activities. Therefore, in order to measure the shadow economy, Schneider does not include the illegal activities (e.g. drug dealing, smuggling, money laundering, and embezzlement), production of households for own final use or any non-observed informal activities being part of the informal sector. All these activities are very difficult to measure and this is why Schneider does not count on them in his attempt to estimate the level of the shadow economy.

Under this narrower definition, shadow economy has two main components (Schneider 2013). The first component, representing a large share (roughly two-thirds) is undeclared work which refers to the wages that workers and businesses do not declare to avoid taxes or labor market regulation. The second component (roughly one third) is represented by business underreporting income to avoid some of the tax burden.

In this research, the terms, definitions and measurements of shadow economy are used according to the view of Schneider and his colleagues. Therefore, when we refer to shadow economy, we deal only with the activities that are concealed from public authorities and we do not deal with illegal, household or informal activities. Schneider's database (Schneider, 2013) where shadow economy is calculated as a percentage of the official GDP is used. Period 2008-2013 is taken into considered (for 2013 estimations are used). Schneider's databases regarding measures of shadow economy are widely used by various authors such as Nastav and Bojnec (2008), Torgler (2002, 2004, 2008), ATKearney (2013) but also by European Commission (2014).

\subsection{Measuring the independent variable - happiness}

The analyze of the relationship between happiness and shadow economy or tax morale is few addressed in literature. But, as far as it is found, different estimates of the happiness are used. For example, by examining the determinants of tax morale in countries from Asia, Torgler (2004) uses the happiness variable as it is estimated by World Value Survey Data (WVS). The same database (WVS) is used by Tekeli (2011) in order to find out if happiness or well-being can explain tax morale in two countries (Japan and Turkey). Trying to explain the determinants of shadow economy, Thießen (2010) also uses the database provided by the World Value Survey regarding the estimation of happiness and life satisfaction. For the first time, Thießen (2010) invokes some estimation of happiness by using data consisting of the "happy planet index" from the New Economics Foundation in relation with shadow economy, but he has not used it in any empirical research.

Happy Planet Index (HPI) is one of the first global measures of sustainable well-being. It was introduced in 2006 by the New Economics Foundation and it was provided by Centre for Well-being at NEF (the New Economics Foundation). Happy Planet Index (HPI) measures the longevity, happiness and sustainability. It looks for the countries where people live long and happy without damaging the planet (Bergheim 2007). The HPI attracted 
worldwide attention as a complex indicator which encapsulates three dimensions of human life such as life expectancy, experienced well-being and ecological footprint with formula:

\section{Happy planet index $\approx$ (Experienced Well-being $x$ Life Expectancy)/Ecological Footprint.}

HPI index ranges from 0 points (weak) to 100 points (strong) in measuring happiness. The Experienced Well-being component measures from 0 to 10 points (where 0 represents the worst possible life and 10 the best possible life) how good people's life is at a particular point in time. The Life Expectancy component consists of universally important measures of health, as number of life years. The Ecological Footprint component targets the sustainable side of the HPI index and it is a per capita measure of land required to sustain a country's consumption patterns (it is expressed in global hectares ( $\mathrm{g}$ ha)).

In our research we use the Happy Planet Index (HPI) as proxy for people's feeling happy according to the last edition of the Happy Planet Index 2012 Report (Happy Planet Index 2012; Abdallah et al. 2012). For more analytical results, we use the HPI index from a structural approach in terms of its components.

HPI is widely used in different studies (Abdallah et al. 2009, 2012; Bergheim 2007; Johns, Ormerod 2007; Goossens et al. 2007; Stiglitz et al. 2010), but it has never been addressed (to our knowledge) in empirical researches of the shadow economy. The advantage of HPI compared to other indicators of happiness is that HPI combines the well-being component with ecological issues, offering a more sustainable side of well-being. In this sense, HPI is a mixture between subjective and objective criteria (Goossens et al. 2007). Also, HPI can be used successfully as an alternative for the GDP, as long as the actual needs of society demonstrate that generally the ultimate aim of most people is not to be rich, but to be happy and healthy in an ecological world. HPI index is determined for a large number of countries (151 countries) so it's degree of comparability is very high. Given these advantages of HPI index compared to other measures of happiness, we prefer this for our research.

\subsection{Selected control variables}

Our paper investigates the relationship between shadow economy and happiness. We have to control a number of other important factors widely used in literature, such as public governance, fiscal burden and richness of a country. They will be discussed as follows.

\subsubsection{Public governance}

Friedman et al. (2000) empirically show that corrupt countries have a higher share of unofficial economy. Following Friedman, various studies (Torgler 2005; Torgler, Schneider 2007; Dreher, Schneider 2006) are focused on explaining the role of governance on the shadow economy. Also, Torgler (2005) find that direct democratic rights and local autonomy have a significantly positive effect on the size of shadow economy and later Dreher and Schneider (2006) find that an increase of index of corruption by one point increases the level of shadow economy (express as percent in GDP) by 1.5-3.5 percentage points.

Investigating specialized studies, Kirchler (2007) concluded that shadow activities increase as the confidence in governance shows a decrease, the tax morale deteriorates and 
the official regulations on economic activities multiply. The study of Richardson (2006) shows that trust is negatively related to tax evasion. Therefore, low trust in tax authorities is correlated with high levels of tax evasion. Also, the study of Kogler et al. (2013) confirms the role of trust and power as important determinants of tax compliance and states that the highest level of tax compliance and the lowest level of tax evasion was found in conditions of high trust and high power in governance. Thus, in recent years, trust in governmental authorities as well as tax morale and motivational postures have been investigated with regard to their influence on tax evasion (Torgler 2005; Kogler et al. 2013; Pickhardt, Prinz 2014; Prinz et al. 2014; Antoci et al. 2014).

Therefore, the following secondary hypothesis can be stated:

Hypothesis 2. A higher level of public governance decreases the size of shadow economy.

In addition we intend to test if the results significantly differ for the old and new members of EU. Therefore, the following research question is stated:

Research question 2. How the results of testing hypothesis 2 differ for the two groups of EU countries (EU OLD and EU NEW)?

Many authors address the concept of "governance" as being very difficult to define and quantify by help of just one indicator or a combination of more indicators that could show all the dimensions of governance (Andrews 2008; Kaufmann et al. 2010; Boța-Avram 2014). Nevertheless, the attempts of the World Bank with the help of its specialists in this field, namely Kaufmann, Kraay and Masstruzii are worth mentioning. They have tried to develop a governance score named Worldwide Governance Indicators (WGI). Such a score was used by numerous researchers who investigated the determining causes of the shadow economy in different countries (Torgler, Schneider 2007; Thießen 2010). The Worldwide Governance Indicators (WGI) provided by the World Bank (2013) have summarized the views on the quality of governance provided by a large number of enterprises, citizens and expert survey respondents under some aggregate and individual governance indicators for 215 economies over the period of 1996-2012, for six dimensions of governance, as follows (World Bank 2013): a) Voice and Accountability (VA) which captures the freedom of expression, the freedom of association, and the free media; b) Political Stability and Absence of Violence (PS) evaluates measured perceptions of the likelihood that the government would be destabilized or overthrown; c) Government Effectiveness (GE) captures perceptions of the quality of public services, their ability to produce and implement good policies and deliver public goods; d) Regulatory Quality (RQ) captures perceptions of the ability of the government to formulate and implement sound policies and regulations that allow and promote the development of the private sector (it also includes perceptions of the burdens imposed by excessive regulations); e) Rule of Law (RL) reflects the extent to which agents have confidence in and compliance with the rules of society, property rights, police and courts, as well as the likelihood of crime and violence; f) Control of Corruption (CC) highlights the extent to which public power is exercised for private gain.

Each component ranges from -2.5 (weak) to 2.5 (strong) in governance performance. We are going to check the robustness of the statistical results for the governance score by using all single sub-scores independently. 
Based on the six governance components, Hypothesis 2 and Research question 2 can be divided as follows:

Hypothesis 2.1. Good Voice and Accountability (VA) diminishes the level of shadow economy.

Research question 2.1. How the results of testing hypothesis 2.1 differ for the two groups of EU countries (EU OLD and EU NEW)?

Hypothesis 2.2. Good Political Stability and the Absence of Violence (PS) diminishes the level of shadow economy.

Research question 2.2. How the results of testing hypothesis 2.2 differ for the two groups of EU countries (EU OLD and EU NEW)?

Hypothesis 2.3. Good Government Effectiveness (GE) diminishes the level of shadow economy.

Research question 2.3. How the results of testing hypothesis 2.3 differ for the two groups of EU countries (EU OLD and EU NEW)?

Hypothesis 2.4.Good Regulatory Quality $(R Q)$ diminishes the level of shadow economy.

Research question 2.4. How the results of testing hypothesis 2.4 differ for the two groups of EU countries (EU OLD and EU NEW)?

Hypothesis 2.5. Good Rule of Law (RL) diminishes the level of shadow economy.

Research question 2.5. How the results of testing hypothesis 2.5 differ for the two groups of EU countries (EU OLD and EU NEW)?

Hypothesis 2.6. Good Control of Corruption (CC) diminishes the level of shadow economy. Research question 2.6. How the results of testing hypothesis 2.6 differ for the two groups of EU countries (EU OLD and EU NEW)?

\subsubsection{Fiscal burden}

The literature about the effect of tax systems on corporate behavior reveals that economical underground activities aggravate as the real and perceived fiscal burden rises (Frey, Weck-Hannemann 1984; Devereux, Griffith 2003; Schneider, Klinglmair 2004; Devereux, De Mooij 2009). For policy-makers, knowing about the trend of the fiscal revenue is very important in order to assure the budget equilibrium in perspective (Mara et al. 2009). The survey of OECD (2009) also supports the assumption that high tax rates leads to discrete locations of profitable investments by multinationals. Sweden is a good example of a state with a high level of fiscal pressure and unwanted effects of taxes. In 1970-1980 the government entailed the most drastic progressive income tax system among industrialized states and the marginal tax rates raised the unemployment rate to $80-90 \%$. The excessive fiscal pressure generated high levels of tax evasion (Agnell, Persson 2000). The same findings are supported by Putniņš and Sauka (2011) in their study in the Baltic States (Latvia, Estonia and Lithuania). They found that dissatisfaction with the tax system and the government offers an explanation of the size of shadow economy in these countries.

High levels of taxation determine the migration of investors towards other countries which are "fiscal oases" or "fiscal havens" to obtain a more favorable fiscal treatment. 
According to OECD criteria (OECD 2009), a fiscal paradise is defined by "none or few nominal taxes on the relevant income, lack of transparency, lack of effective exchange of information, none substantial activities". In addition, every country which meets the above criteria is required to make commitments to implement the principles of transparency and exchange of information for tax purposes. Economic analysts say that approximately $70 \%$ of the world currency is run by the tax havens (Buziernescu, Antonescu 2007).

Nevertheless, there are studies which do not agree with the existence of a causal relationship between tax burden and the size of shadow economy (Friedman et al. 2000; Dreher, Schneider 2006; Torgler, Schneider 2007). Making a big survey on OECD countries between 1980 and 2004, Kawano and Slemrod (2014) also found that the relationship between corporate tax rates and corporate tax revenues is tenuous.

Based on the assumptions above, we intend to assert the following hypothesis and research question:

Hypothesis 3. The higher the fiscal burden, the higher the shadow economy.

Research question 3. How the results of testing hypothesis 3 differ for the two groups of EU countries (EU OLD and EU NEW)?

According with Schneider et al. (2010) the measurement of fiscal burden is not easy to define because the tax and social security systems are vastly different among countries. The fiscal burden can be estimated in various ways:

a) as total tax rate (\% of commercial profits) - $\mathrm{TAX}_{1}$ (positive sign is expected);

b) as tax revenue (\% of GDP) - TAX $_{2}$ (positive sign is expected);

c) as fiscal freedom variable, a subcomponent of the Heritage Foundation's economic freedom index - $\mathrm{TAX}_{3}$ (negative sign is expected); it includes both the direct tax burden in terms of the top tax rates on individual and corporate incomes and the overall amount of tax revenue as percentage of GDP. The index ranges from 0 to 100 , where 0 is the least fiscal freedom and 100 is the maximum degree of fiscal freedom (Heritage Foundation 2015).

The last proxy of fiscal burden is more complex being preferred by various authors in their research (Torgler 2002; Dreher, Schneider 2006; Torgler, Schneider 2007).

\subsubsection{Wealth of a country}

Various studies certify that a higher level of development generates a better capacity of paying and collecting taxes and a greater demand for public goods and services (Torgler 2004; Torgler et al. 2010). For example, the empirical research conducted by Torgler (2004) reveals a strong relationship between financial satisfaction and tax payment and finally he concludes that "if the financial situation of a household is bad, the tax payments might be seen as a hard restriction of their possibility set, which might reduce tax honesty".

Furthermore, investigating the findings of Schneider (Alm et al. 2004; Schneider 2013; Schneider et al. 2015; Schneider, Klingmair 2004) the highest rates of shadow economy activities can be found in developing and in transition countries. In Africa and South America, $41 \%$ of the economic activities are clandestine. In European states in economic transition, shadow economy is estimated at $38 \%$. Countries with lowest shadow economy 
activities are Switzerland, the USA and Austria. In the meantime Bolivia and Georgia lead with over 66\% (Kirchler 2007: 16). These findings are also supported by the study of Orviska and Hudson (2003) who find that in developed countries tax fraud is estimated to be $20 \%$ of the total income and in developing countries the percentage is even higher. Similar results were obtained in other countries with different levels of development per region. Therefore, Brosio et al. (2002) investigate tax fraud in different regions of Italy and find that in the poorer Southern regions tax fraud is significantly greater than in the wealthier Northern regions. The authors explain that the underground economy and tax noncompliance are possible expressions of the population's disagreement regarding the provision of public goods and insurance of welfare by the state.

Therefore, we assess the following hypothesis and research question:

Hypothesis 4. Increasing richness of a country is associated with a lower propensity towards shadow economy.

Research question 4. How the results of testing hypothesis 4 differ for the two groups of EU countries (EU OLD and EU NEW)?

Gross Domestic Product (GDP) is a very used indicator measuring for the level of development and prosperity of a country. A higher level of development goes together with a greater capacity to pay and collect taxes, as well as a higher relative demand for public goods and services (Chelliah 1971). Following Torgler and Schneider (2007) we are going to use per capita GDP as a measure for the richness of a country.

\subsection{Equation model and data}

Our research is conducted on European Union member countries, consisting of 28 states at the time of the study. We intend to find whether or not is any difference between the old and the new entrants in the European Union, in terms of shadow economy and its explanatory factors. We are going to use the term "old members" with the symbol "EU OLD" to refer to the first 15 members that joined the EU until the $30^{\text {th }}$ of April 2004, as following: Belgium, Denmark, France, Germany, Greece, Ireland, Italy, Luxembourg, Netherlands, Portugal, Spain, the United Kingdom, Austria, Finland and Sweden. Moreover, we are going to use the term "new members" with the symbol "EU NEW" represented by the last 13 countries that have joined the EU since the 1st May 2004, namely: Cyprus, Czech Republic, Estonia, Hungary, Latvia, Lithuania, Malta, Poland, Slovakia, Slovenia, Bulgaria, Romania and Croatia. For all the European Union members, we are going to use the symbol "EU ALL".

In order to show whether happiness induces a lower level of shadow economy, we used some largely used control variables. We proposed the following baseline equation model:

$$
\mathrm{SE}_{\mathrm{i}}=\beta_{0}+\beta_{1} \mathrm{HAPPY}_{\mathrm{i}}+\beta_{2} \mathrm{GOV}_{\mathrm{i}}+\beta_{3} \mathrm{TAX}_{\mathrm{i}}+\beta_{4} \mathrm{RICH}_{\mathrm{i}}+\varepsilon_{\mathrm{i}},
$$

where: $\mathrm{SE}_{\mathrm{i}}$ reflects the level of a country's shadow economy, estimated by percentage in the GDP; HAPPY ${ }_{i}$ is the happiness of a country estimated by Happy Planet Index (HPI); 
$\mathrm{GOV}_{\mathrm{i}}$ denotes the quality of public governance, estimated by World Governance Indicators (WGI); TAX $_{\mathrm{i}}$ is the fiscal burden estimated: as total tax rate (as the percent of commercial profits- $\mathrm{TAX}_{1}$ ); as tax revenue (as the percentage of $\mathrm{GDP}^{-\mathrm{TAX}_{2}}$ ); as fiscal freedom variable variable, a subcomponent of the Heritage Foundation's economic freedom index-TAX . $_{3}$ $\mathrm{RICH}_{\mathrm{i}}$ is the wealth of a country, estimated by per capita GDP; $\varepsilon_{\mathrm{i}}$ reveals the error term.

The data refers to the period of 2008-2013 and were collected as follows:

- Shadow economy is determined as a percentage of the official GDP calculated by Schneider (2013) over the period of 2008-2013 (for 2013 the estimations are used);

- Happy Planet Index (HPI) is provided by the Centre for Well-being at the New Economics Foundation;

- World Governance Indicator (WGI) is collected from the World Bank;

- Fiscal burden estimates by $\mathrm{TAX}_{1}$ and $\mathrm{TAX}_{2}$ are provided by World Bank. $\mathrm{TAX}_{3}$ is provided by The Heritage Foundation;

- Per capita GDP is provided by the World Bank.

The model is estimated with the help of the Ordinary Least Square (OLS) method by using cross-section data and the average values for the years 2008-2013 are used. Firstly, we analyzed whether independent variables are not multi collinear by using the correlation matrix of the independent variables. Then, the " $T$ " test was used in order to test the significance of the coefficients. The overall significance of the model was tested by using the "F" test. R-squared shows the extent to which the variation of the dependent variable is explained by the independent variables in the model.

\section{Results and discussions}

\subsection{Descriptive statistics}

As first step, we proceed to a short descriptive statistics of the level of shadow economy (SE) as shown in Table 2.

The level of shadow economy for all European Union' members is about 19.56 percents (in GDP), this means that about one-fifth of EU GDP is lost in the shadow economy, in average over the period 2008-2013. New members have an average level of shadow economy calculated as percentage in GDP of 25.42 percents, while among the old members the percentage is only 14.48 percents. It can be seen that the difference between old and new members of the European Union in terms of shadow economy is significant being a good argue for us to conduct a separate analysis of the shadow economy on these two subgroups in order to explain this variation. Among all the countries of the European Union, the lowest percentage of the shadow economy is found in Austria (7.97 percents), followed by Luxembourg (8.35 percents) and Netherlands (9.7 percents). Opposite, the highest level of the shadow economy is found in Bulgaria (with 32.1 percent), followed by Romania (29.32 percents) and Lithuania (28.98 percents). 
Table 2. The size of shadow economy (SE)-as percent in GDP, in EU countries (2008-2013 average)

\begin{tabular}{|c|c|c|c|}
\hline EU OLD & SE & EU NEW & SE \\
\hline Austria & $7.97 \%$ & Bulgaria & $32.10 \%$ \\
\hline Belgium & $17.17 \%$ & Croatia & $29.40 \%$ \\
\hline Denmark & $13.73 \%$ & Cyprus & $25.92 \%$ \\
\hline Finland & $13.67 \%$ & Czech Republic & $16.35 \%$ \\
\hline France & $10.95 \%$ & Estonia & $28.72 \%$ \\
\hline Germany & $13.78 \%$ & Hungary & $22.87 \%$ \\
\hline Greece & $24.43 \%$ & Latvia & $26.50 \%$ \\
\hline Ireland & $12.67 \%$ & Lithuania & $28.98 \%$ \\
\hline Italy & $21.52 \%$ & Malta & $25.52 \%$ \\
\hline Luxembourg & $8.35 \%$ & Poland & $24.97 \%$ \\
\hline Netherlands & $9.70 \%$ & Romania & $29.32 \%$ \\
\hline Portugal & $19.20 \%$ & Slovak Republic & $15.95 \%$ \\
\hline Spain & $19.20 \%$ & Slovenia & $23.95 \%$ \\
\hline Sweden & $14.66 \%$ & & \\
\hline United Kingdom & $10.33 \%$ & & \\
\hline Groups & Mean & Std. Dev. & Max. \\
\hline EU ALL & $19.56 \%$ & 7.33 & $32.1 \%$ \\
\hline EU OLD & $14.48 \%$ & 4.91 & $24.43 \%$ \\
\hline EU NEW & $25.42 \%$ & 4.84 & $32.1 \%$ \\
\hline
\end{tabular}

\subsection{Testing hypotheses and research questions}

Secondly, we are going to test the working hypothesis and the appropriated research questions (H1, RQ1; H2, RQ 2; H3, RQ3; H4, RQ 4).

Testing the Hypothesis 1. Increasing human happiness is associated with a lower propensity towards shadow economy and the Research question 1. How the results of testing hypothesis 1 differ for the two groups of EU countries (EU OLD and EU NEW)? involve the analysis of the Tables 3 and 4 .

In Table 3 the pairwise correlations of the SE (Shadow economy), HPI (Happy Planet Index) and WELB (Well-being) variables for EU ALL are presented. We found a very week correlation between HPI and SE (coef. $=-0.29$ ) and a strong correlation between WELB and SE (coef. $=-0.78)$.

Table 3. Correlation Matrix (between SE, HPI and WELB)

\begin{tabular}{r|ccc}
\hline \multicolumn{4}{c}{ EU ALL } \\
\hline SE & HPI & WELB \\
SE $\mid 1.0000$ & & \\
HPI $\mid$ & -0.2980 & 1.0000 & \\
WELB $\mid$ & -0.7801 & 0.4255 & 1.0000 \\
\hline
\end{tabular}


The Well-being component of the HPI is strongly correlated with SE, while by adding other components (life-expectancy or foot print) the effect on SE considerably diminishes. This result is also supported by other studies which used the variable individual's well-being as an estimator for the happiness (Tekeli 2011). In such a context, Roubal and Havliček (2013) remark that the concept of happiness could encapsulate many meanings and a variety of denotations in social sciences, such as the quality of life, life satisfaction, subjective well-being, level of positive emotions etc.

In Table 4 the linear regressions between shadow economy (SE) and well-being (WELB) for EU countries and separately for the new and the old EU members are presented.

Table 4. Linear regression between SE and WELB

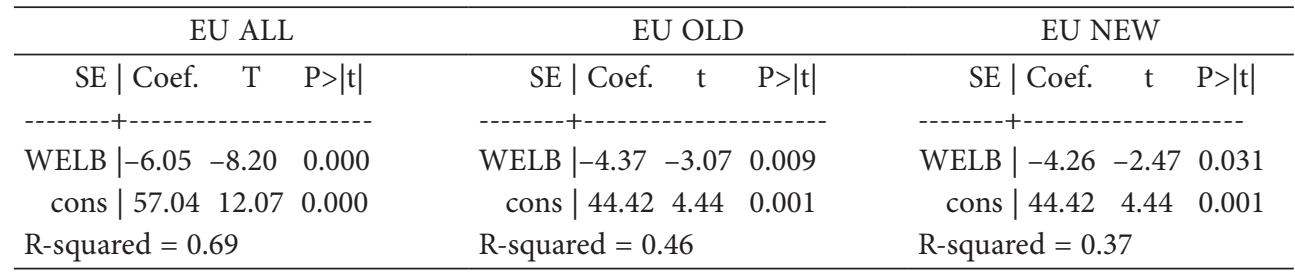

From Table 4 we can find a linear relationship between WELB and SE statistically significant at a significance level of $1 \%(\mathrm{p}$-value $=0.000)$, for EU ALL. The sign of WELB coefficient is the expected one, being negative. If WELB increases with one point, SE decreases with approximately 6.055 points. The well-being variable explains the level of shadow economy in percent of $69.63 \%(\mathrm{R}$-squared $=0.6963$ ). In conclusion, according to our findings, well-being is a representative measure for happiness with a significant impact on the size of shadow economy in the European Union countries. Also, by considering well-being as a proxy for happiness, we found that happiness could be a determinant for the shadow economy. Therefore, the hypothesis $\mathrm{H} 1$ is valid.

As regards the results on the two groups of countries, from Table 4 we can find they differ to a certain degree. For the EU OLD sample the influence of WELB is statistically significant at a significance level of $1 \%$ (p-value $=0.009)$ but for the EU NEW the influence is statistically significant only at a significance level of $5 \%(p$-value $=0.031$ ). For the EU OLD sample the well-being variable explains the level of shadow economy in percent of $46 \%$ (Rsquared $=0.46)$ and for the EU NEW sample the percent of explanation is somehow lower, of $37.47 \%$ (R-squared $=0.37$ ). In other words, in both cases the relationship is statistically significant but for the EU OLD countries the impact of happiness on the shadow economy is slightly higher than in the EU NEW countries.

Testing the Hypothesis 2. A higher level of public governance decreases the size of shadow economy with its components (H.2.1., H2.2., H2.3., H2.4., H2.5., H.2.6.) and Research question 2. How the results of testing hypothesis 2 differ for the two groups of EU countries (EU OLD and $E U N E W$ )? with its components (R.2.1., R2.2., R2.3., R2.4., R2.5., R.2.6.) involve the data of the Tables 5 and 6. 
From Table 5 we find out that the low levels of correlation coefficients between SE and RL, and between SE and CC for EU NEW raises questions on the validity of the hypotheses H2.5. and H2.6. for these countries. In Table 6 we run the linear regressions between shadow economy and public governance with its components, for the countries which belong to EU ALL and separately for EU OLD and EU NEW.

For EU ALL we found a strong and negative correlation (coef. $=-0.7914$ ) between the shadow economy (SE) and the public governance (WGI) (Table 5). From Table 6 we find that the relationship between the two variables is confirmed at a significance level of $1 \%$ ( $p$-value $=0.000)$. The negative sign of the coefficient reflects that a higher quality of public governance leads to a decrease of the underground activities in the European Union countries. If the quality of public governance increases by one point, the shadow economy reduces by 1.9 points. Therefore, the hypothesis $\mathrm{H} 2$ is validated for the EU member states (EU ALL).

Table 5. Correlation Matrix (between SE, WGI, VA, PS, GE, RQ, RL and CC)

\begin{tabular}{|c|c|c|c|c|c|c|c|c|}
\hline EU ALL | & SE & WGI & VA & PS & GE & RQ & $\mathrm{RL}$ & CC \\
\hline $\mathrm{SE}$ & | 1.0000 & & & & & & & \\
\hline WGI | & -0.7914 & 1.0000 & & & & & & \\
\hline VA | & -0.8172 & 0.9704 & 1.0000 & & & & & \\
\hline PS & -0.5126 & 0.6856 & 0.6100 & 1.0000 & & & & \\
\hline GE | & -0.7466 & 0.9744 & 0.9314 & 0.6160 & 1.0000 & & & \\
\hline RQ | & -0.7767 & 0.9424 & 0.9171 & 0.5634 & 0.8990 & 1.0000 & & \\
\hline RL | & -0.7801 & 0.9751 & 0.9595 & 0.5757 & 0.9524 & 0.9329 & 1.0000 & \\
\hline $\mathrm{CC}$ & -0.7651 & 0.9761 & 0.9515 & 0.5737 & 0.9524 & 0.9098 & 0.9524 & 1.0000 \\
\hline
\end{tabular}

EUOLD | SE WGI VA PS GE RQ RL CC

SE | 1.0000

WGI | -0.79501 .0000$

VA | $\begin{array}{llll}-0.7728 & 0.9840 & 1.0000\end{array}$

PS | $\begin{array}{lllll}-0.6307 & 0.8177 & 0.8074 & 1.0000\end{array}$

GE | $\begin{array}{llllll}0.7315 & 0.9745 & 0.9466 & 0.7268 & 1.0000\end{array}$

RQ | $\begin{array}{lllllll}-0.7981 & 0.9470 & 0.9379 & 0.6820 & 0.9045 & 1.0000\end{array}$

$\mathrm{RL} \mid \begin{array}{llllllll}-0.8334 & 0.9701 & 0.9334 & 0.7085 & 0.9608 & 0.9428 & 1.0000\end{array}$

CC $\mid \begin{array}{lllllllll}-0.7732 & 0.9858 & 0.9754 & 0.7351 & 0.9750 & 0.9381 & 0.9624 & 1.0000\end{array}$

EU NEW | SE WGI VA PS GE RQ RL CC

SE | 1.0000

WGI | -0.49991 .0000$

VA $\mid \begin{array}{lll}-0.5558 & 0.9649 & 1.0000\end{array}$

PS | - $\begin{array}{lllll}0.5707 & 0.6975 & 0.7180 & 1.0000\end{array}$

GE | $\begin{array}{llllll}-0.4366 & 0.9430 & 0.8469 & 0.6110 & 1.0000\end{array}$

RQ | - - $\begin{array}{lllllll}0.5059 & 0.8475 & 0.8505 & 0.4086 & 0.7560 & 1.0000\end{array}$

RL | - $\begin{array}{llllllll}0.4011 & 0.9663 & 0.9281 & 0.6040 & 0.8795 & 0.8572 & 1.0000\end{array}$

CC | - - $\begin{array}{lllllllll}0.3272 & 0.9249 & 0.8726 & 0.5047 & 0.8782 & 0.7155 & 0.8932 & 1.0000\end{array}$ 
Table 6. Linear regression between SE and WGI (also including the components of WGI)

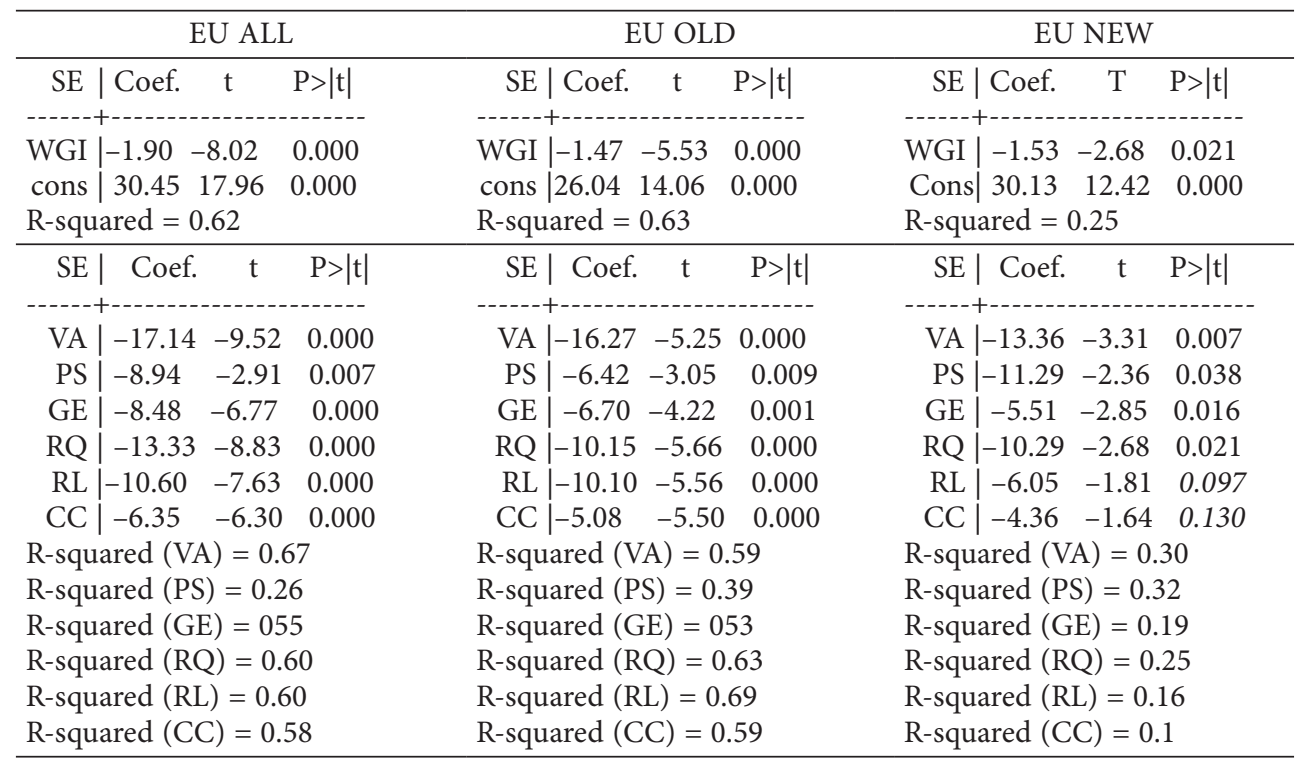

From the summary presented in Table 6, we find out which ones of the six secondary hypotheses (H2.1, H2.2, H2.3, H2.4, H2.5 and H2.6) are accepted. For EU ALL, we found that between the SE variable and each variable components of the WGI (VA, PS, GE, RQ, $\mathrm{RL}$ and CC) there is a linear relationship which is confirmed at a significance level of $1 \%$ (all p-values < 0.01). The Voice and Accountability (VA) component seems to have the highest negative impact on the level of shadow economy (the coefficient is -17.14 and also R-squared is 0.67). In conclusion, for EU ALL, all the secondary hypotheses H2.1., H2.2., $\mathrm{H} 2.3$., H2.4., H2.5. and H2.6. are accepted at a significance level of $1 \%$. This means that a Good Voice and Accountability (VA), a good Political Stability, a high Absence of Violence (PS), a good Government Effectiveness (GE), a good Rule of Law (RL) and a good Control of Corruption (CC) determine a reduction of the level of shadow economy in the European Union member states.

As regards finding answers to our research questions (RQ2 and its components RQ2.1., RQ2.2. RQ2.3., RQ2.4., RQ2.5. and RQ2.6.) we also used the data from Table 5 and 6.

Checking for EU OLD sample, from Table 6 we see a statistically significant relationship between the shadow economy (SE) and the public governance (WGI) confirmed at a significance level of $1 \%(\mathrm{p}$-value $=0.000)$. The WGI coefficient is the expected one (a negative one -1.47 ) and the impact of the public governance on shadow economy is about $63.21 \%$ (R-squared $=0.63$ ). An increase of one point of the quality of public governance determines a decrease of $1.47 \%$ of the shadow economy (lower than in EU ALL). Therefore, we document that for EU OLD the core hypothesis $\mathrm{H} 2$ is also validated.

Regarding the new members (EU NEW), from Table 5, we find a medium and negative correlation between shadow economy (SE) and public governance (WGI) (coef. $=-0.49$ ). Table 6 reveals a linear and negative influence of WGI on SE, statistically significant at a sig- 
nificant level of $5 \%$ ( $p$-value $=0.021$ ). For the EU NEW sample, the variation of the shadow economy is explained in percent of $25 \%$ by the quality of public governance (R-squared = 0.3 ). The percent is much lower than in the EU OLD sample (where the R-squared $=0.63$ ). So, the hypothesis $\mathrm{H} 2$ is also validated for the EU NEW sample.

To respond to our research question (RQ2.), for the EU OLD countries the impact of public governance on the shadow economy is higher than in the EU NEW countries, but in both cases it is statistically significant.

Going to the components of public governance, from Table 5 we find that all secondary hypotheses H2.1., H2.2., H2.3., H2.4., H2.5. and H2.6. are also valid for EU OLD sample at a significance level of $1 \%$ (p-values $<0.01$ ). As for the EU NEW countries, the hypotheses $\mathrm{H} 2.1$., H2.2., H2.3. and H2.4. are confirmed at a significance level of 5\% while the hypothesis H.2.5. is accepted only at 10\% significance level. For EU NEW, we also find a negative impact of Control of Corruption (CC) on shadow economy (SE) but it is not statistically significant $(\mathrm{p}$-value $=0.131$ ), therefore the hypothesis H2.6. is rejected. The variation of the shadow economy due to the variation of each governance components is explained in percents of maximum $32 \%$ in the EU NEW sample compared with a much higher percent of maximum $69 \%$ for EU OLD.

To respond to our research questions (RQ2.1., RQ2.2., RQ2.3., RQ2.4.), for the EU OLD countries the impact of Voice and accountability (VA), Political Stability and Absence of Violence (PS), Government Effectiveness (GE) and Regulator Quality (RQ) on the shadow economy is significantly higher than in the EU NEW countries. For both samples, the relationships are significant but for the EU NEW only at a level of significance of 5\%. A similar result is found for the research questions RQ2.5. where we also find for EU OLD a strong and negative influence of the Rule of Law (RL) on shadow economy but for the EU NEW the relationship is significant, this time, only at $10 \%$ level of significance. As for RQ2.6., a higher Control of Corruption (CC) reduces the shadow economy (SE) for both groups of the countries, but for the EU NEW the result is not statistically significant.

Concluding, our results are in line with those of Torgler (2005), Torgler and Schneider (2007) and Kirchler (2007) who find out the quality of governance has a strong impact on reducing the level of shadow economy.

However, for EU NEW our findings point out that the increase of control of corruption determines a decrease of the level of shadow economy, but the results are not significant for these countries. Investigating the research literature (Johnson et al. 1997; Choi, Thum 2005; Dreher, Schneider 2006) it seems that the relation between corruption and shadow economy is still not well settled, being found either positive or negative. Moreover, the relation may depend on the way of measure the corruption, as perceived corruption or as actual corruption, once other relevant factors are controlling for (Weber Abramo 2005; Mocan 2008). Trying to deal this, Dreher and Schneider (2006) point out there is reason to believe that this relationship might differ among high and low income countries. They found evidence that the sign of relationship even can differ from one group to another. More specifically, the corruption and shadow economy are found to be substitutes in high income countries and complements in low income countries. The authors explain this by different mechanisms which prevail each type of the countries. Therefore the public goods 
provided by the official sector are in many developing countries less efficient than in high income ones and this is the reason for a largely part of entrepreneurs (such restaurants, bars or haircutters or even bigger production companies) to pay a bribe in exchange to stay unofficial. Thus, in developing countries, the corruption and shadow economy are found to be substitutes. In comparison, in the high income countries, the public goods is more efficient and here, only small firms take the option to go underground by paying bribes but the big companies often bribe official to get a contract from the public sector (e.g. in the construction sector). So, this contract is then conducted in the official sector not in shadow economy. Under these reasons, in high income countries the corruption and shadow economy are expected to be found as complements. Based on these interesting findings and return to our results, we see that all the EU NEW members are emerging countries with an average income of about 15960 per capita GDP compared with an average of 46263 per capita GDP for EU OLD members. Thus, under this context, the different results regards the impact of control of corruption on shadow economy among the two groups, could be largely explained.

Testing the Hypothesis 3. The higher the fiscal burden, the higher the shadow economy and Research question 3. How the results of testing hypothesis 3 differ for the two groups of $E U$ countries (EU OLD and EU NEW)? involve the analysis of the Tables 7 and 8.

Table 7. Correlation Matrix (between SE, $\mathrm{TAX}_{1}, \mathrm{TAX}_{2}$ and $\mathrm{TAX}_{3}$ )

\begin{tabular}{|c|c|c|c|c|c|c|c|c|c|c|c|c|c|}
\hline \multicolumn{5}{|c|}{ EU ALL } & \multicolumn{5}{|c|}{ EU OLD } & \multicolumn{4}{|c|}{ EU NEW } \\
\hline & SE & TAX $_{1}$ & $\mathrm{TAX}_{2}$ & $\mathrm{TAX}_{3}$ & & SE & $\mathrm{TAX}_{1}$ & $\mathrm{TAX}_{2}$ & $\operatorname{TAX}_{3}$ & & SE & $\mathrm{TAX}_{1}$ & $\mathrm{TAX}_{2} \mathrm{TAX}_{3}$ \\
\hline SE & 1.00 & & & & SE & 1.00 & & & & SE & 1.00 & & \\
\hline $\operatorname{TAX}_{1}$ & -0.11 & 1.00 & & & $\operatorname{TAX}_{1}$ & 0.40 & 1.00 & & & $\operatorname{TAX}_{1}$ & -0.41 & 1.00 & \\
\hline $\mathrm{TAX}_{2}$ & -0.13 & -0.35 & 1.00 & & $\operatorname{TAX}_{2}$ & -0.21 & -0.40 & 1.00 & & $\mathrm{TAX}_{2}^{1}$ & 0.20 & -0.43 & 1.00 \\
\hline $\mathrm{TAX}_{3}$ & 0.64 & -0.27 & -0.38 & 1.00 & $\mathrm{TAX}_{3}$ & 0.09 & -0.33 & -0.34 & 1.00 & $\operatorname{TAX}_{3}^{2}$ & 0.18 & 0.14 & -0.5 \\
\hline
\end{tabular}

Table 8. Linear regression between SE and fiscal burden $\left(\mathrm{TAX}_{1}, \mathrm{TAX}_{2}, \mathrm{TAX}_{3}\right)$

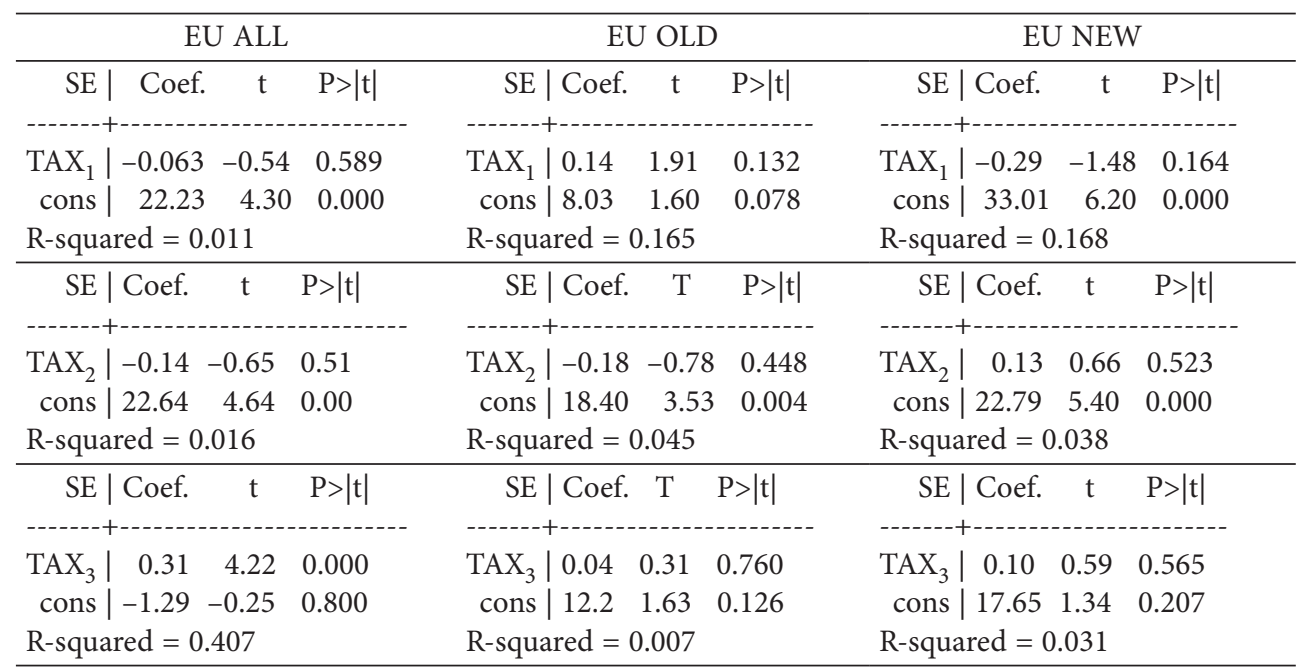


From Table 7 and 8 we find out some interesting results. Let's check firstly the results for EU ALL, by using the three proxy used for fiscal burden. The absolute values of correlation coefficients show a strong correlation when $\mathrm{TAX}_{3}$ is used (coef. $=0.64$ ) and a very weak correlation when $\mathrm{TAX}_{1}$ and when $\mathrm{TAX}_{2}$ are used (coef. are -0.11 and -0.13). As regards the signs of the correlations coefficients, surprisingly, for all the three variables they show unexpected results. As we specified before in the Section 2, for $\mathrm{TAX}_{1}$ and $\mathrm{TAX}_{2}$ positive signs are expected and for $\mathrm{TAX}_{3}$ a negative sign is expected, but our results are opposite.

Analyzing Table 8, the conclusions become more completed. The negative coefficients of $\mathrm{TAX}_{1}$ and $\mathrm{TAX}_{2}$ from the linear regressions are unexpected meaning that the higher the fiscal burden, the smaller shadow economy. But the relationships are not significant ( $\mathrm{p}$-values $=0.5>0.05)$. Going to the third fiscal burden proxy $\left(\operatorname{TAX}_{3}\right)$ we can find some similar results but much more robust. In this case, the coefficient is positive but also opposite to our expectations. According to our result, a higher fiscal freedom meaning a lower fiscal pressure conducts also to a higher shadow economy. So, by adding another proxy for fiscal burden $\left(\mathrm{TAX}_{3}\right)$ the relationship became statistically significant at a level of significance of $1 \%(p$-value $=0.000)$. Also, fiscal freedom explain $40.7 \%$ from the volume of shadow economy, but out of the economic theory because the sign of the coefficient is not the expected one. All in all, the Hypothesis 3 is rejected, meaning that a higher fiscal burden does not necessarily lead to a higher level of the shadow economy in the EU countries.

However, our findings are supported by various studies that point out such similarly results. Therefore, Friedman et al. (2000) and later Dreher and Schneider (2006) find that higher tax rates imply smaller shadow activities. Furthermore, in line with our findings, Torgler and Schneider (2007) state about "mixed empirical evidence" on the correlations between fiscal burden and shadow economy found in the literature. Moreover, in their study conducted in 55 countries over the period 1990 to 1999, Torgler and Schneider (2007) do not find a consistently statistically significant correlation between the fiscal burden and shadow economy. Kawano and Slemrod (2014) also find a weak relationship between corporate tax rates and corporate tax revenues at least on short-term, but do not exclude a stronger relationship on long-term.

In what regards our research question whether or not the results differ for the two groups of EU countries (EU OLD and EU NEW), the answer is yes. By using TAX $_{1}$ and $\mathrm{TAX}_{2}$ the sign of coefficients are opposite from one group to another, meaning that both expected and unexpected evidences are found. By using $\mathrm{TAX}_{3}$ (which is a much more complex proxy for fiscal burden) the similar signs of the coefficients for the two groups are found (unexpected positive signs) so the higher fiscal freedom meaning a lower fiscal burden, the higher shadow economy. However, by using all the three proxies, the results are not statistically significant for any of the two groups.

In conclusion, our results are mixed among the two groups. In most cases, we found contrary evidences, that a higher fiscal burden determines a lower propensity to perform shadow activities, but we also found some expected evidences. Such mixed empirical evidences are also find by Torgler and Schneider (2007). A good explanation of these mix results among the two groups could be related to the way of measure the fiscal burden 
because the tax and social security systems are vastly different among countries (Schneider et al. 2010) and due to this reason, the values could not be fully comparable.

Testing the Hypothesis 4. Increasing richness of a country is associated with a lower propensity towards shadow economy and the Research question 4. How the results of testing hypothesis 4 differ for the two groups of EU countries (EU OLD and EU NEW)? involve the analysis of the Tables 9 and 10 .

Table 9. Correlation Matrix between SE and GDP

\begin{tabular}{|c|c|c|c|c|c|c|c|c|}
\hline \multicolumn{3}{|c|}{ EU ALL } & \multicolumn{3}{|c|}{ EU OLD } & \multicolumn{3}{|c|}{ EU NEW } \\
\hline & SE & GDP & | & SE & GDP & 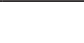 & SE & GDP \\
\hline SE & 1.0000 & & SE & 1.0000 & & SE & 1.0000 & \\
\hline GDP & -0.7251 & 1.0000 & GDP & -0.6138 & 1.0000 & GDP & -0.4047 & 1.0000 \\
\hline
\end{tabular}

Table 10. Linear regression between SE and GDP

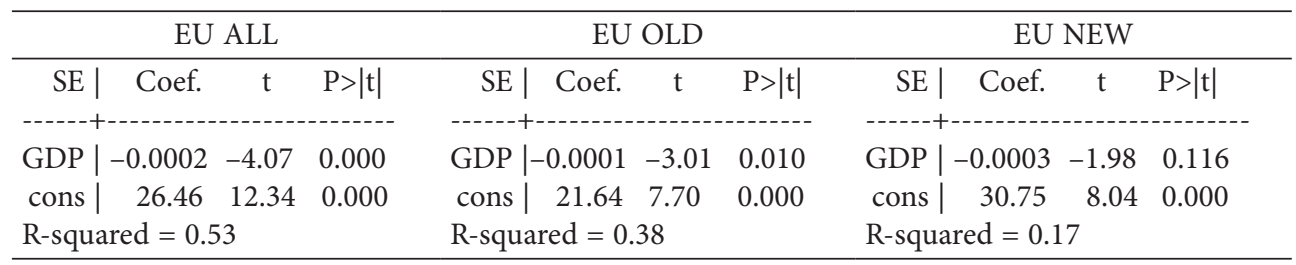

Table 9 shows that the correlation's sign between SE and per capita GDP is negative, so we can state the hypothesis H4 (for all EU member states, both old and new). In Table 10, we can find for EU ALL that the results are in line with our expectations meaning that a higher per capita GDP is associated with a smaller shadow economy and this relationship is confirmed at a significance level of $1 \%(\mathrm{p}$-value $=0.000)$. It is important to highlight that, for all EU sample the impact of per capita GDP variable on the shadow economy is high, being 53\%. Thus, the hypothesis H4 is valid for EU ALL, meaning that the increasing richness of a country is associated with a lower propensity towards shadow economy for European Union members.

Regards our research question RQ4, we see from Table 10 that for EU OLD sample the hypothesis $\mathrm{H} 4$ is valid also at a significance level of $1 \%$ ( $\mathrm{p}$-value $=0.01$ ). For the EU NEW sample even the influence is those expected (as negative), it is not statistically significant ( $\mathrm{p}$-value $=0.116)$, therefore the hypothesis $\mathrm{H} 4$ are not valid. Also, the impact of per capita GDP on the shadow economy is much higher for EU OLD (of 38\%) than for the EU NEW (only 17\%).

In conclusion, we can say that hypothesis $\mathrm{H} 4$ is valid for EU countries but the impact of the richness of a country on shadow economy is significantly higher for the EU OLD than for the EU NEW. Our findings are in line with previous research (Torgler Schneider, 2007) and confirm the expectation that the richer the country, the smaller the propensity to perform shadow activities. 


\subsection{Validation of the model}

In Table 11 we can find a strong correlation (0.78) between GDP per capita and WGI, which means they are not independent in order to be encapsulated in the model. The variable GDP per capita remains in the model because between GDP per capita and SE there is a strong correlation (coef $=-0.72$ ). Also we find HPI variable as independent in relations with other variables (GDP and WGI).

Table 11. Correlation Matrix (between SE, HPI, GDP, WGI and WELB)

\begin{tabular}{rrrrr}
\hline EU ALL & \multicolumn{1}{c}{ GE } & & & \\
\hline & SE & HPI & GDP & WELB \\
SE | 1.0000 & & & & \\
HPI | -0.2980 & 1.0000 & & & \\
GDP | -0.7251 & -0.0162 & 1.0000 & & \\
WGI | -0.7914 & 0.1895 & 0.7822 & 1.0000 & \\
WELB | -0.7801 & 0.4255 & 0.7852 & 0.8432 & 1.0000 \\
\hline
\end{tabular}

Checking for all statistical tests, finally, we keep in the model HPI and per capita GDP variables. Table 12 shows the models estimated by linear regression between the dependent variable SE and the independent variables HPI and per capita GDP. For EU ALL, the two variables HPI and GDP explain the variance of SE in percent of 62\% (R-squared $=0.62$ ).

For EU ALL the simultaneous influences of HPI and per capita GDP on shadow economy in the model presented in Table 12 do not contradict the hypotheses $\mathrm{H} 1$ and H4. The relationships from the regression are confirmed at a significance level of $1 \%$, therefore the model is valid. The model is also valid for the EU OLD at a significance level of 5\% (HPI p-value $=0.025$ and GDP $\mathrm{p}$-value $=0.001)$. In this case the variable HPI and per capita GDP explain the variation of SE in percent of $60 \%$ (R-squared $=0.60$ ). But for the EU NEW sample we find that the simultaneous influences of HPI and per capita GDP on SE are not statistically significant (HPI p-value $=0.814$ and GDP p-value $=0.149$ ), therefore for this sample, the model is not valid.

The attempt to introduce the fiscal burden variable (expressed by $\mathrm{TAX}_{1}, \mathrm{TAX}_{2}$ and $\mathrm{TAX}_{3}$ ) in the model along with HPI and GDP, was unsuccessful which does not contradict the results of testing hypothesis $\mathrm{H} 3$.

Table 12. Models for EU ALL, EU OLD and EU NEW

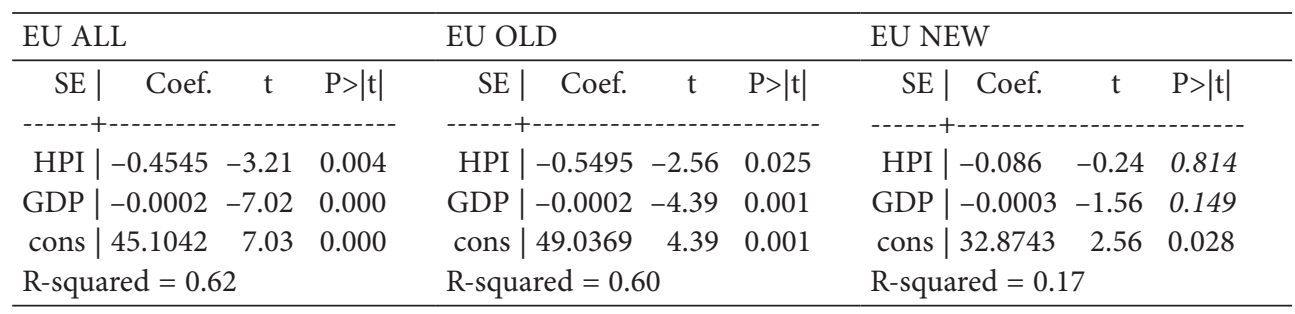


Analyzing many other combinations of variables we could not get to a more relevant model than the above fit models presented in Table 12, available for EU ALL and EU OLD. These models encapsulate the variables happiness (HPI) and richness (per capita GDP) as the main determinants of the size of shadow economy for EU ALL and also for EU OLD. Regards the public governance we previous found that it influence on shadow economy (ceteris paribus) and therefore the Hypothesis 2 was validated. However, the relationship between public governance and shadow economy are never significant when the happiness and richness variables are included in the regression. This is a very important results which our model points out supporting the assumption that if the people are simultaneously happy and rich, they are not likely anymore to go underground and any other factor such public governance or fiscal burden seems to not matter for shadow economy. A higher level of happiness and income reduce the shadow economy with coefficients significant at $1 \%$ (for all sample) and respectively 5\% (for EU OLD). The variation of shadow economy in both cases is explained in the percent of about $60 \%$ by these two main found variables. As regards, for the EU NEW countries, any statistically significant model of the shadow economy could be found (the p-values of the variables' influences are significantly higher than $1 \%, 5 \%$ or even $10 \%)$.

The results are those expected and mentioned in Introduction where we state that the variation of the shadow economy can be differentially explained by the factors which characterize these emerging countries. The specific features of emerging economies which are commonly recognized could alter the major forces which play an active role in economy.

\section{Conclusions}

Over time, in spite of the fact that numerous studies have tried to analyse the impact of the psychological factors on the economic behaviour of people, few studies have put into question whether the well-being and happiness can affect the level of shadow economy (Schneider, Klinglmair 2004; Bergheim 2007; Thießen 2010) and the results are not fully convincing. The present research aims to study the shadow economy through some psychological factors, especially human happiness. Therefore, the main contribution of this research is the finding that happiness is a significant determinant of the shadow economy in the European Union countries.

Another main contribution consists of the systematic comparisons between old and new Member States in terms of determinants of the shadow economy. New members have an average level of shadow economy of $25.42 \%$ (calculated as a percentage in GDP), while among the old members the percentage is only $14.48 \%$. The impact of happiness on shadow economy is higher for the old EU members than for the new EU members, and in both cases the correlations are statistically significant.

In addition, we found the quality of public governance is associated with a lower propensity towards shadow economy in EU countries. The relationships are significantly higher in the old EU members than in the new ones. Our results are in line with those of Torgler (2005), Torgler and Schneider (2007) and Kirchler (2007) who stress the impor- 
tance of extending the morale or subjective dimensions of shadow economy's determinants by highlighting the trust in public governance's dimension.

As for the influences of various components of public governance on shadow economy, each of them is found to be negative and significant for all sample and for the old members. Regards the new members, the impact of Voice and accountability (VA), Political Stability and Absence of Violence (PS), Government Effectiveness (GE), Regulator Quality (RQ) and Rule of Law (RL) on shadow economy is also negative but significant only at $5 \%$ and $10 \%$ level of significance. The influence of Control of Corruption (CC) on shadow economy is found to be negative but not statistically significant for the new members. Therefore, this factor seems to not be determinant for shadow economy in these countries. However, our finding are somehow in line with those of Dreher and Schneider (2006). They find evidence to believe that this relationship might differ among high and low income countries and they explain this by different mechanisms which prevail each type of the countries. By linking to our results, because the EU NEW members have an average of per capita GDP three times lower than the EU OLD members, the different mechanisms which characterizing high and low income countries mentioned by Dreher and Schneider (2006), could be also used here as explanations for the different results regards the impact of control of corruption on shadow economy by the two groups.

Another interesting finding, contrary to our expectations, consists of the fact that the fiscal burden seems not to be a determinant for the shadow economy in the European Union space. To get a high robustness results, the fiscal burden is estimated by three variables: total tax rate (as \% of commercial profit), tax revenue (\% of GDP) and the fiscal freedom index (provided by Heritage Foundation). Even if these results were surprising for us, they are similar to those of various author who used some similar estimators for tax burden (Friedman et al. 2000; Dreher, Schneider 2006; Torgler, Schneider 2007; Kawano, Slemrod 2014). They also found out that tax burden is not correlated with shadow economy and their results were also confirmed by using various robustness checks test (various estimators for tax burden). The explanation could be related to the different way of measure the fiscal burden for each country and regarding this Schneider et al. (2010) also remark that the tax and social security systems are vastly different among countries.

In line with our expectations, we find that the richness of a EU countries significantly matters for staying in the official sector. The richer the country, the smaller the propensity to perform shadow activities. Nevertheless, for the old EU members, the relationship is significantly stronger.

In the context of aforesaid, the main added value of our research consists of the finding that happiness is a determinant of the shadow economy in the European Union countries. Moreover, some econometric models that include the happiness and richness variables as the main determinants of the size of shadow economy have been made and are valid for EU ALL sample and also for EU OLD. Following our expectations mentioned in the Introduction, the model is not valid for EU NEW countries, even some core hypothesis are valid (at a lower level of significance). As we expect, the variation of the shadow economy are differentially explained by the factors which characterize each of the two groups such as the legislation context, privatisation, ownership structure, social, cultural, political and 
economic structures and also the strength of the Europeanization's process. Facing the principles of the new social era of capitalism, the emerging countries have to adjust their behaviour in order to point out the real drives of economy.

Our research point out that the variation of shadow economy is explained in the percent of about $60 \%$ by richness and happiness for EU sample and the percent is even more higher (62\%) for the EU OLD sample. If the richness variable was largely known in literature as being a main determinant for shadow economy, finding happiness as being so consists in the main finding of this research. The results are in line with those of the few researches found in the literature in this field (Schneider, Klinglmair 2004; Bergheim 2007; Thießen 2010). They also also happiness among the main determinants of the shadow economy. Moreover, Thießen (2010) find also happiness and life satisfaction among the first three factors with an impact upon the level of shadow economy in a list of 67 factors.

Related to Torgler and Schneider's study (2007), our results come again to stress the importance of extending the complexity of the issue by considering the moral and psychological dimensions. Even though most economics tend to base their analysis on neoclassic theory, the complexity of phenomenon requires further study when trying to understand why people are involved in shadow activities. Rational neoclassic determinants of tax evasion and shadow economy tend to be covered by irrational determinants such as subjective perceptions, attitude and motivations, which are growing great importance in explaining the tax behavior. Our results come to support the "slippery-slope model" trust in authorities and voluntary compliance versus power of authorities and enforced compliance (Kirchler 2007) by stressing the role of psychological interventions. The research comes to argue the need of a friendly and happy climate therefore the compliance is likely to occur voluntarily and shadow activities are diminished.

This research may have significant social implications for policy-makers that are seeking for ways of reducing the level of shadow economy in order to safeguard the national economy. Our research suggests that policy-makers need to focus more on the subjective channels than on objective ones in order to get a lower propensity towards shadow economy, in the process of policy reforms which should be undertaken. Furthermore, the policy-makers need to act mainly in order to stress the intrinsic motivation of people in order to stay in the official sector and to comply with their tax obligations, by increasing the trust in public institutions and also by stressing the feeling of happiness among the tax payers ("happy taxpayers"). In addition, our results confirm the expectation that a higher income remains one of the neoclassic ways to motivate individuals to engage in activities no longer underground. Therefore, the policy-makers need to know these and to find channels focused on external motivations consist in increasing the income in order to motivate people to act in the official sector.

Moreover, our findings come to stress the idea of Stiglitz et al. (2010) and Oswald (2010) about the importance of measuring a nation's emotional prosperity rather than its economic prosperity, focusing on well-being than wealth. The attempt to use a Gross National Happiness measuring the overall social well-being as an alternative for Gross Domestic Product measuring only the economic well-being is more than never required by current research and police-makers should know this. In this context, our findings focused on re- 
thinking the shadow economy in terms of happiness come to highlight these requirements by stressing the role of societal welfare comparing to the economic prosperity, as a main determinants for shadow economy. The use of a global indicator measuring both economic and emotional prosperity by the policy-makers would be the best in order to better explain more economic phenomena, here the shadow economy.

As limitations of the research it may be invoked the using of only one measure for happiness, those provided by Happy Planet Index. Therefore, in order to reduce that limits, in the future work we have in mind to rely on the other measures for happiness (provided by other world publicly databases such as World Value Survey). Also, in order to substantiate our findings we intend to test our results on the other samples of countries.

\section{Acknowledgements}

The paper has much benefited from the discussions of an earlier draft within the CEBSS seminar, Babeș-Bolyai University, January 29, 2015, Cluj-Napoca, Romania and WEI International Academic Conference, April 12-15, 2015, Vienna, Austria. The authors wish to thank Adrian Zoicaș-Ienciu for his valuable assistance in improving the quality of this manuscript within the CEBSS seminar. The authors are also very grateful to the blind reviewers for theirs insightful and constructive comments and suggestions. The responsibility for any error belongs to the authors.

\section{References}

Abdallah, S.; Michaelson, J.; Shah, S.; Stoll, L.; Marks, N. 2012. The Happy Planet Index: 2012 Report. A global index of sustainable well-being. nef, London.

Abdallah, S.; Thompson, S.; Michaelson, J.; Marks, N.; Steuer, N. 2009. The (un)Happy Planet Index 2.0. Why good lives don't have to cost the Earth. nef, London.

Alm, J.; Martinez-Vazquez, J.; Torgler, B. 2005. Russian attitudes toward paying taxes - before, during, and after the transition, CREMA Working Paper 2005-27. Center for Research in Economics, Management and the Arts, Basel. http://dx.doi.org/10.1016/s0573-8555(04)68802-x

Alm, J.; Martinez-Vazquez, J.; Schneider, F. 2004. Sizing the problem of the hard-to tax, in Contributions to Economic Analysis, vol. 268. Elsevier, 11-75.

Alm, J.; Torgler, B. 2004. Culture differences and tax morale in the United States and Europe, CREMA Working Paper 2004-14. Center for Research in Economics, Management and the Arts, Basel.

Andrews, M. 2008. The good governance agenda: beyond indicators without theory, Oxford Development Studies 36(4): 379-407. http://dx.doi.org/10.1080/13600810802455120

Agnell, J.; Persson, M. 2000. Tax arbitrage and labour supply, Journal of Public Economics 78(1-2): 3-24. http://dx.doi.org/10.1016/S0047-2727(99)00109-7

Antoci, A.; Russu, P.; Zarri, L. 2014. Tax evasion in a behaviourally heterogeneous society: an evolutionary analysis, Economic Modelling 42: 106-115. http://dx.doi.org/10.1016/j.econmod.2014.06.002

Akay, A.; Bargain, O.; Dolls, M.; Neumann, D.; Peichl, A.; Siegloch, S. 2012. Happy Taxpayers? Income taxation and well-being. Discussion Paper No. 6999, November 2012. IZA, Bonn, Germany.

ATKearney. 2013. The shadow economy in Europe, 2013 [online], [cited November 2014]. Available from Internet: http://www.atkearney.com/documents/10192/1743816/The+Shadow+Economy+in + Europe+2013.pdf 
Barone, G.; Mocetti, S. 2009. Tax morale and public spending inefficiency. Temi di discussione (Economic working papers), 732, Bank of Italy, Economic Research and International Relaions Area.

Bergheim, S. 2007. The happy variety of capitalism. Deutsche Bank Research, April 25, 1-22.

Boța-Avram, C. 2014. Good governance and doing business: evidence from a cross-country survey, Transylvanian Review of Administrative Sciences 41: 27-45.

Brosio, G.; Cassone, A.; Ricciuti, R. 2002. Tax evasion across Italy: rational noncompliance or inadequate civic concern?, Public Choice 112(3-4): 259-273. http://dx.doi.org/10.1023/A:1019985022106

Buziernescu, R.; Antonescu, M. 2007. Paradisurile fiscale international, Finance - Challenge of the Future 6: 178-189.

Chelliah, R. J. 1971. Trends in taxation in developing countries, Staff Papers (International Monetary Fund) 18: 254-331. http://dx.doi.org/10.2307/3866272

Choi, J.; Thum, M. 2005. Corruption and the Shadow Economy, International Economic Review 46(3): 817-836. http://dx.doi.org/10.1111/j.1468-2354.2005.00347.x

Coricelli, G.; Rusconi, E.; Villeval, M. C. 2014. Tax evasion and emotions: an empirical test of reintegrative shaming theory, Journal of Economic Psychology 40: 49-61.

http://dx.doi.org/10.1016/j.joep.2012.12.002

Devereux, M. P.; De Mooij, R. A. 2009. Alternative systems of business tax in Europe: an applied analysis of ACE and CBIT reforms. Study for the European Commission, DG Taxation and Customs Union.

Devereux, M. P. ; Griffith, R. 2003. Evaluating tax policy for location decisions, International Tax and Public Finance 10: 107-126. http://dx.doi.org/10.1023/A:1023364421914

Dreher, A.; Schneider, F. 2006. Corruption and the Shadow economy. An empirical analysis. Working paper 2006, CREMA Gellerstrasse 24-CH-4052.

Earnhart, D.; Lizal, L. 2007. Does better environmental performance affect revenues, cost, or both? Evidence from a transition economy. William Davidson Institute Working Paper Number 856.

European Commission. 2014. Shadow economy and undeclared work [online], [cited July 2015]. Available from Internet: http://ec.europa.eu/europe2020/pdf/themes/07_shadow_economy.pdf

Eurostat. 2014. Essential SNA: building the basics. 2014 ed. Luxembourg: Publications Office of the European Union.

Falkner, G.; Treib, O. 2008. Three worlds of compliance or four? The EU-15 Compared to New Member States, Journal of common market studies 46(2): 293-313. http://dx.doi.org/10.1023/A:1023364421914

Friedman, E.; Johnson, S.; Kaufmann, D.; Zoido-Lobaton, P. 2000. Dodging the grabbing hand: the determinants of unofficial activities in 69 countries, Journal of Public Economics 76(3): 459-493. http://dx.doi.org/10.1016/S0047-2727(99)00093-6

Frey, B. S.; Stutzer, A. 2012. The use of happiness research for public policy, Social Choice and Welfare 38(4): 659-674. http://dx.doi.org/10.1007/s00355-011-0629-Z

Frey, B. S.; Weck-Hannemann, H. 1984. The hidden economy as an "unobserved" variable, European Economic Review 26(1): 33-53. http://dx.doi.org/10.1016/0014-2921(84)90020-5

Goetz, K. H. 2001. Making sense of post-communist central administration: modernization, Europeanization or Latinization?, Journal of European Public Policy 8(6): 1032-1051. http://dx.doi.org/10.1080/13501760110098332

Goossens, Y.; Mäkipää, A.; Schepelmann, P.; Van de Sand, I.; Kuhndt, M.; Herrndorf, M. 2007. Alternative progress indicators to gross domestic product (GDP) as a means towards sustainable development. European Parliament, Policy Department A: Economic and Scientific Policy, Brussels.

Grabbe, H. 2001. How does Europeanization affect CEE governance? Conditionality, diffusion and diversity, Journal of European Public Policy 8(6): 1013-1031. http://dx.doi.org/10.1080/13501760110098323

Halla, M. 2010. The link between the intrinsic motivation to comply and compliance behavior: a critical appraisal of existing evidence. IZA Discussion Paper. 
Happy Planet Index (HPI) [online]. 2012 [cited November 2014]. Available from Internet: http://www. happyplanetindex.org/data/

Harbaugh, W. T.; Mayr, U.; Bughart, D. R. 2007. Neural responses to taxation and voluntary giving reveal motives for charitable donations, Science 316(5831): 1622-1625. http://dx.doi.org/10.1126/science.1140738

Heritage Foundation. 2015. Index of Economic Freedom. Washington DC.

Johns, H.; Ormerod, P. 2007. Happiness, economics and public policy. The Institute of Economic Affairs, London.

Johnson, S.; Kaufmann, D.; Sleifer, A. 1997. The unofficial economy in transition, Brooking Papers on Economic Activity 2: 159-221. http://dx.doi.org/10.2307/2534688

Kahneman, D.; Krueger, A. B.; Schkade, D.; Schwarz, N.; Stone, A. A. 2006. Would you be happier if you were richer? A focusing illusion, Science 312: 1908-1910. http://dx.doi.org/10.1126/science.1129688

Kaufmann, D.; Kraay, A.; Mastruzzi, M. 2010. The worldwide governance indicators methodology and analytical issues. Policy Research Working Paper 530, The World Bank Development Research Group Macroeconomics and Growth Team, 1-28.

Kawano, L.; Slemrod, J. 2014. How do corporate tax bases change when corporate tax rates change? With implications for the tax rate elasticity of corporate tax revenues [online], [cited November 2014]. Available from Internet: http://www.sbs.ox.ac.uk/sites/default/files/Business_Taxation/Events/conferences/2014/iipf_summer_school/kawano-slemrod.pdf

Kirchler, E. 2007. The economic psychology of tax behavior. Cambridge, England: Cambridge University Press. http://dx.doi.org/10.1017/CBO9780511628238

Kogler, C.; Batrancea, L.; Nichita, A.; Pantya, J.; Belianin, A. 2013. Trust and power as determinants of tax compliance: testing the assumptions of the slippery slope framework in Austria, Hungary, Romania and Russia, Journal of Economic Psychology 34: 169-180.

http://dx.doi.org/10.1016/j.joep.2012.09.010

Lubian, D.; Zarri, L. 2011. Happiness and tax morale: an empirical analysis, Journal of Economic Behavior \& Organization 80(1): 223-243. http://dx.doi.org/10.1016/j.jebo.2011.03.009

Mahadeo, J. D.; Soobaroyen, T.; Hanuman, V. O. 2012. Board composition and financial performance: uncovering the effects of diversity in an emerging economy, Journal of Business Ethics 105(3): 375388. http://dx.doi.org/10.1007/s10551-011-0973-Z

Mara, E. R.; Inceu, A.; Cuceu, I.; Achim, M. V. 2009. The impact of economic crisis on the fiscal revenues, Annals of Faculty of Economics 3(1): 252-257.

Mocan, N. 2008. What determines corruption? International evidence from micro data, Economic Inquiry 46(4): 493-510. http://dx.doi.org/10.1111/j.1465-7295.2007.00107.x

Nastav, B.; Bojnec, Š. 2008. Small business and the shadow economy, Czech Journal of Economics and Finance 58(1-2): 68-80.

OECD. 2012. Communication from the Commission to the European Parliament and the council on concrete ways to reinforce the fight against tax fraud and tax evasion including in relation to third countries. COM/2012/0351.

OECD. 2009. Overview of OECD's work on international tax evasion.

OECD. 2008. Non-observed economy in national accounts. Survey Country/Practices. United Nations.

OECD. 2002. Measuring the Non-observed Economy-A Handbook.

Orviska, M.; Hudson, J. 2003. Tax evasion, civic duty and the law abiding citizen, European Journal of Political Economy 19(1): 83-102. http://dx.doi.org/10.1016/S0176-2680(02)00131-3

Oswald, A. J. 2010. Emotional prosperity and the Stiglitz commission. IZA Discussion Paper No. 5390, December. 
Pickhardt, M.; Prinz, A. 2014. Behavioral dynamics of tax evasion - a survey, Journal of Economic Psychology 40: 1-19. http://dx.doi.org/10.1016/j.joep.2013.08.006

Prinz, A.; Muehlbacher, S.; Kirchler, E. 2014.The slippery slope framework on tax compliance: an attempt to formalization, Journal of Economic Psychology 40: 20-34. http://dx.doi.org/10.1016/j.joep.2013.04.004

Putniňš, T. J.; Sauka, A. 2011. Size and determinants of shadow economies in the Baltic States, Baltic Journal of Economics 11(2): 5-25. http://dx.doi.org/10.1080/1406099X.2011.10840498

Richardson, G. 2006. Determinants of tax evasion: a cross-country investigation, Journal of International Accounting, Auditing and Taxation 15(2): 150-169. http://dx.doi.org/10.1016/j.intaccaudtax.2006.08.005

Robinson, J. P.; Shaver, L. S. 1991. Wrightsman: measures of personality. New York: Academic Press.

Roubal, O.; Havliček, K. 2013. The role of happiness in the economic environment, Journal of Social Sciences 2(2): 15-23.

Schmölders, G. 1960. Fiscal psychology: a new branch of public finance, National Tax Journal 12: 340-345.

Schneider, F.; Raczkowski, K.; Mróz, B. 2015. Shadow economy and tax evasion in the EU, Journal of Money Laundering Control 18(1): 34-51. http://dx.doi.org/10.1108/JMLC-09-2014-0027

Schneider, F. 2013. Size and development of the shadow economy of 31 European and 5 other OECD countries from 2003 to 2013: a further decline [online], [cited November 2014]. Available from Interent: http://www.econ.jku.at/members/schneider/files/publications/2013/shadeceurope31_jan2013.pdf

Schneider, F. 2011. The shadow economy and shadow economy labor force: what do we (not) know? IZA Discussion paper, No. 5769.

Schneider, F.; Buehn, A.; Montenegro, C. E. 2010. New estimates for the shadow economies all over the world, International Economic Journal 24(4): 443-461.

http://dx.doi.org/10.1080/10168737.2010.525974

Schneider, F. 2005. Shadow economies of 145 countries all over the world: estimation results of the period 1999 to 2003. Discussion Paper. Linz.

Schneider, F.; Klinglmair, R. 2004. Shadow economies around the world: what do we know? Working Paper No. 0403, Universität Linz.

Stiglitz, J. E.; Sen, A.; Fitoussi, J.-P. 2010. Mismeasuring our lives: why GDP doesn't add up. Commission on the Measurement of Economic Performance and Social Progress, New Press.

Tekeli, R. 2011. The determinants of tax morale: the effects of cultural differences and politics. PRI Discussion Paper Series (No.11A-10), Policy Research Institute, 1-77.

Thießen, U. 2010. The shadow economy in international comparison: options for economic policy derived from an OECD panel analysis. Discussion Papers, Deutsches Institut für Wirtschaftsforschung, 1-72.

Torgler, B.; Schneider, F.; Schaltegger, C. A. 2010. Local autonomy, tax morale and the shadow economy, Public Choice 144: 293-321. http://dx.doi.org/10.1007/s11127-009-9520-1

Torgler, B. 2008. What do we know about tax fraud? An overview of recent developments, Social Research 75(4): 1239-1270.

Torgler, B.; Schneider, F. 2007. The impact of tax morale and institutional quality on the shadow economy. IZA Discussion Paper.

Torgler, B. Schneider, F. 2009. The impact of tax morale and institutional quality on the shadow economy, Journal of Economic Psychology 30(2): 228-245. https://doi.org/10.1016/j.joep.2008.08.004

Torgler, B. 2005. Tax morale in Latin America, Public Choice 122: 133-157. http://dx.doi.org/10.1007/s11127-005-5790-4

Torgler, B. 2004. Tax morale in Asian Countries, Journal of Asian Economics 15: 237-266. http://dx.doi.org/10.1016/j.asieco.2004.02.001 
Torgler,B. 2002. The economic analysis of "creative" compliance. WWZ-Discussion Paper 02/04, Basel, WWZ.

Tosun, J. 2014. Absorption of regional funds: a comparative analysis, Journal of Common Market Studies 52(2): 371-387. http://dx.doi.org/10.1111/jcms.12088

Voicu, C. 2012. Underground economy nature - conceptual status, Theoretical and Applied Economics XIX 3(568): 109-120.

Weber Abramo, C. 2005. How far Perceptions go. Transparency Brazil Working Paper, The World Bank, Whashington DC.

Weck, H. 1983. Schattenwirtschaft: Eine Möglichkeit zur Einschränkung der öffentlichen Verwaltung? Eine ökonomische Analyse. Finanzwissenschaftliche Schriften 22. Bern: Lang.

World Bank. 2013. Worldwide governance indicators 2013. [online], [cited September 2014]. Available from Internet: www.govindicators.org

Monica Violeta ACHIM. She is Associate Prof. Phd Habil. She teaches Financial Analysis and Financial Diagnosis and is also Fiscal consultant member of Romanian Tax Consultant Chamber, Accounting expert, member of Romanian Accounting Experts. She is also involved in solving many fiscal and accounting problems of the business environment.

Sorin Nicolae BORLEA. Prof. Phd, he teaches Public Finance, Accounting and Financial Analysis and is also Fiscal consultant member of Romanian Tax Consultant Chamber, Accounting expert, member of Romanian Accounting Experts. He is also involved in solving many fiscal and accounting problems of the business environment.

Lucian Vasile GĂBAN. He is economist PhD. He works as economist in “1 Decembrie 1918” University isnstitution, area of research is finance and banking.

Ionut Constantin CUCEU. He is Assistant professor Phd. He teaches public finance and fiscality and is also Accounting expert, member of Romanian Accounting Experts. 